Original Research Paper

\title{
A Comparative Assessment of Heavy Metal Pollution in Soil using pH Enrichment Factor and Pollution Index
}

\author{
${ }^{1}$ Michael Nwachukwu, ${ }^{1}$ Okoro Uwaezu, ${ }^{2}$ Ogbuja I. Ogbuja and ${ }^{3}$ Leonard Nwosu \\ ${ }^{I}$ Department of Environmental Technology, Federal University of Technology Owerri, Nigeria \\ ${ }^{2}$ Department of Environmental Management, Rivers State Univ of Sci and Techn PH, Nigeria \\ ${ }^{3}$ Department of Physics, University of Port-Harcourt, Port-Harcourt, Nigeria
}

Article history

Received: 05-07-2016

Revised: 20-12-2016

Accepted: 07-04-2017

Corresponding Author:

Michael Nwachukwu

Department of Environmental

Technology, Federal University

of Technology Owerri, Nigeria

Email: futo.essg@hotmail.com

\begin{abstract}
Many researchers have described $\mathrm{pH}$ as heavy metals pollution indicator in soil, but no effort has been made to determine level or quantity of heavy metals that could be indicated by $\mathrm{pH}$. This study measured in-situ soil $\mathrm{pH}$ values at Nekede motor mechanic village against the natural background values. We used readings obtained to compute $\mathrm{pH}$ enrichment factor $(\mathrm{pHeF})$ at several measurement points. Pollution index (Pi) data from previous work in the same mechanic village serve as a comparative statistical tool. Result shows that $\mathrm{pHeF}$ have strong relationship with $\mathrm{Pi}$, with correlation coefficient (r): 0.8 . While Pi range was 1.6-2.1, with a mean value of $1.8, p H e \mathrm{~F}$ range was $1.7-2.0$ with same mean value of 1.8. This revelation suggests that in heavy metal contaminated topsoil, $p H e \mathrm{~F}$ tends to $\mathrm{Pi}$. A $p H e \mathrm{~F}$ of 1 implies a Pi of 1 , which indicates zero pollution. In this case, the soil condition for $p H e \mathrm{~F}$ and $\mathrm{Pi}$ is neutral. $p H e \mathrm{~F}<1=$ Alkalinity and $\mathrm{Pi}<1=$ No pollution. $p H e \mathrm{~F}$ $>1=$ Acidity and toxicity of soil at threshold $\leq 5.515$, while $\mathrm{Pi}>1=$ pollution. $p H e \mathrm{~F}$ shows degree of heavy metal contamination in soil for urgent decision making, where $\mathrm{Pi}$ that depends on sophisticated stereoscopic analysis may not be available. Future studies shall consider food security around mechanic villages.
\end{abstract}

Keywords: Soil Acidity, Threshold, Heavy Metals, Pollution, Mechanic Village

\section{Introduction}

A large area of land mapped out by government for automobile repair works within the surrounding area of a city or town is a mechanic village. It is a common practice in Nigeria and many other developing countries for cities to allocate large tracts of land, sometimes reaching 5 ha or more, to groups of small scale motor repair workers. Such places are designated as villages where allied workers and traders also occupy to offer their services to the public. Often these mechanic villages are wrongly sited in urban residential or business areas, For example, the mechanic village in Nekede, Imo state Nigeria (Fig. 1) in the rain forest belt of West Africa has an area of 136 acres with increasing capacity over the past 30 years at the bank of Otamiri River. The Otamiri River is the main source of public water to Owerri metropolis, though the mechanic village is located downstream from the urban water works. For lack of proper planning, the Nekede mechanic village could not resist urban residential and business encroachment after ten years.

A major issue in the mechanic villages is soil degradation arising from regular disposal of spent electrolyte on land by the auto electricians. This practice goes without check or concern of the mechanics most of who are ignorant of the consequences. As a result, there is continuous enrichment of soil $\mathrm{pH}$ within and around mechanic villages. This situation enhances corrosion of different metal objects or scraps metals that litter in mechanic villages. The result is high concentration of heavy metals in mechanic village soil. Acidic soil can prevent plants from absorbing certain nutrients. It can also affect the dispersal of other important nutrients in the soil, creating an imbalance that can block a plant's ability to absorb those nutrients. Testing $\mathrm{pH}$ levels in soil is as important as measuring the degree of metal pollution, the number of mechanic villages in a town or 
city depends on how big the city is. For example, Owerri metropolis has two big mechanic villages: The Nekede and Orji mechanic villages. Satellite towns like Orlu and Okigwe have one mechanic village each. The advantages of mechanic village over a citywide spread of mechanic workshops were originally conceived as: To save automobile owners' the trouble of searching for mechanic specialists. It was also to prevent motorists from falling into the hands of incompetent mechanics and to create opportunities for knowledge sharing among mechanics. They also serve as large scale skill acquisition centers for auto mechanics, auto-electricians, spray-painters, panel beaters and welders, including spare parts dealers. These advantages notwithstanding, the uncontrolled disposal of used electrolytes on the ground remains a major disadvantage.

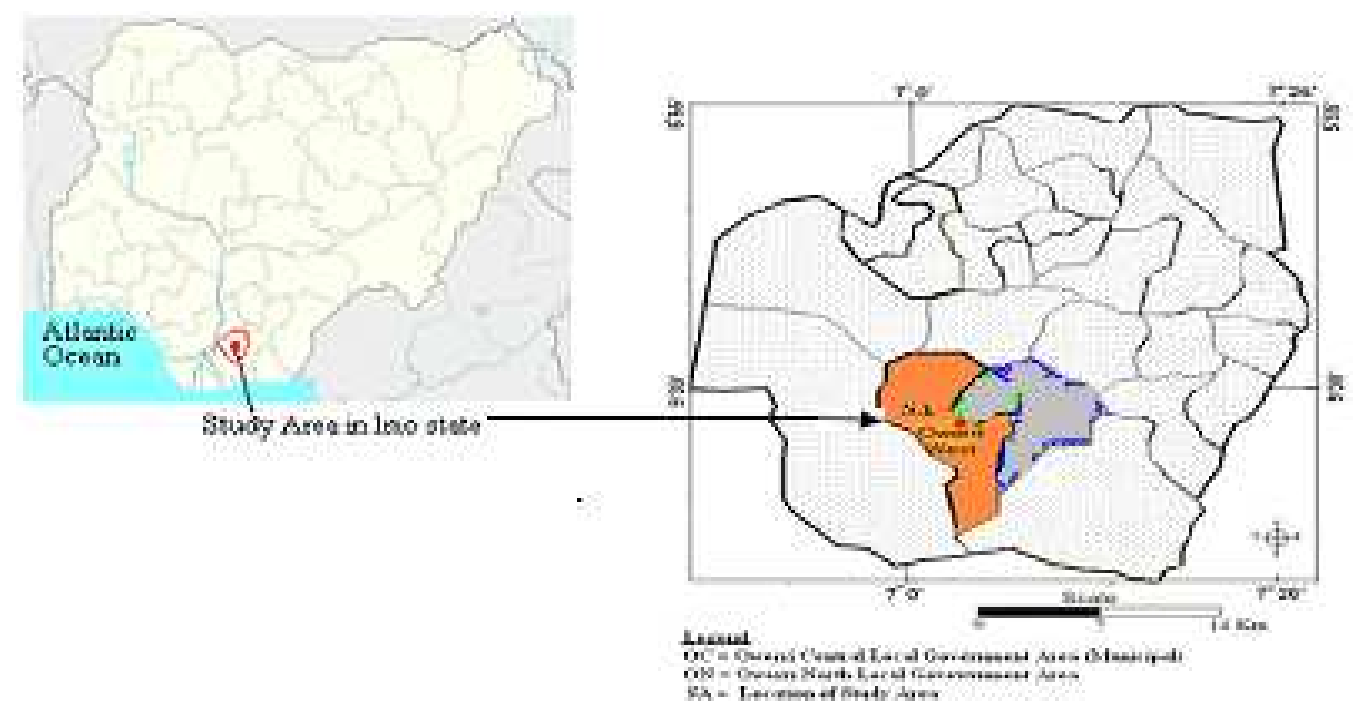

Fig. 1. (a) Map of Nigeria showing Imo state (Left) (b): Map of Imo state showing Owerri West (Right)

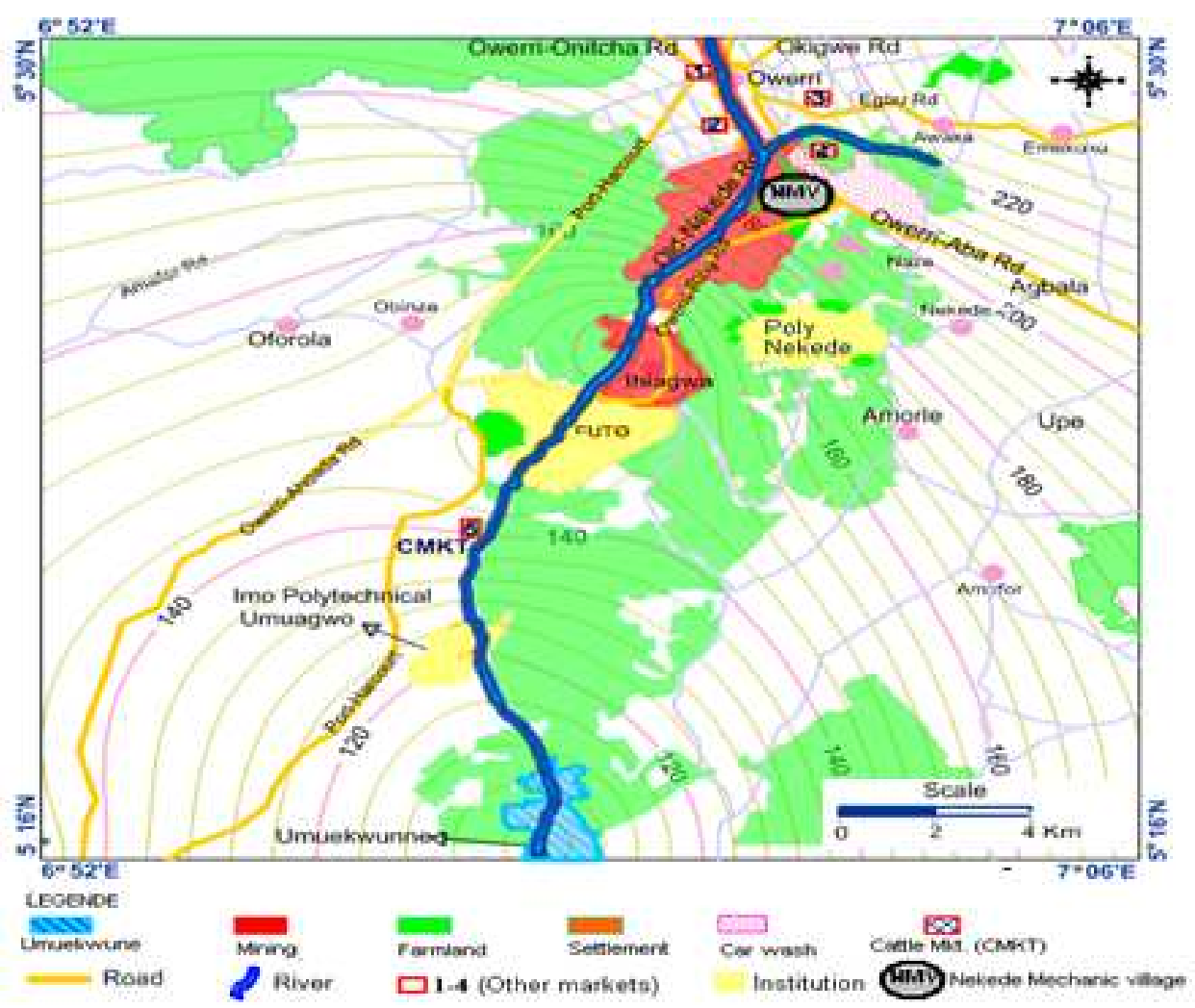

Fig. 2. Showing Nekede mechanic village, the urban setting and environment 
The primary objective of this study is to determine the level of acidity of a contaminated soil such as in mechanic village by computing $\mathrm{pH}$ enrichment factor $(p H e \mathrm{~F})$. Then compare the $\mathrm{pH}$ enrichment factor so obtained with pollution index obtained in the previous studies at Nekede automobile mechanic village soil. This was used to test the relationship between Pollution index (Pi) and $p H e \mathrm{~F}$ as tools for heavy metal pollution assessment of contaminated soils. The study further investigated the possibility of high acidity in the Otamiri River (Fig. 2), where storm water from the Nekede mechanic village discharges.

Soil $\mathrm{pH}$ can change during the year; it depends on temperature and moisture conditions and can vary to as much as a whole $\mathrm{pH}$ unit during the growing season. This study started in May 2013 being the early rain season or a transition period from dry to rain season. Since $\mathrm{pH}$ is a measure of the hydrogen ion $\left[\mathrm{H}^{+}\right]$, many different chemical reactions can affect it. Temperature changes the chemical activity, so most measurements of $\mathrm{pH}$ include a temperature correction to a standard temperature of 25 degrees $(77 * \mathrm{~F})$.

The soil $\mathrm{pH}$ was recorded as a range in values for the soil depth selected. Heavy metal uptake by plants is influenced by different factors specific for soil and plant, such as, temperature, cat ion exchange capacity of the soil and the presence of other heavy metals in the soil. The study area also shows a moderate to high population density, about 104 people per km (NPC, 2006). The moderate topography supports drainage and untreated storm water movement from the mechanic village down slope to the Otamiri River.

\section{Literature Review}

Nwachukwu et al. (2010; 2011; Udebuani et al., 2011) have both reported the Nekede mechanic village soil as highly degraded, having severe to excessive pollution of heavy metals. They have attributed the high concentration of heavy metals in the Nekede mechanic village soil to poor automobile waste management. Nevertheless, there is no known study about the soil $\mathrm{pH}$ level as a function of poor management of spent electrolyte by auto electricians in the village. There is also no detailed work on the impact of disposing spent electrolyte on the ground to the nearby Otamiri River. It is also imperative to say that there is not yet any investigation about the ecological impacts of the poor management of used electrolytes within and around the mechanic village. For example, the impacts of increasing soil acidity to nutrient availability in vegetables and crops planted around the mechanic village within the thirty years of its operations. Disposing spent electrolytes on the ground increases soil acidity; increases bioavailability of trace metals in food crops, causes toxicity and food insecurity. This goes with the primary objectives of this study and the urgent needs for subsequent studies in this direction. So many definitive works carried out in the past globally on soil $\mathrm{pH}$ became necessary because of its ecological implications. Prominent among these is the global soil $\mathrm{pH}$ database put together by the International Geosphere-Biosphere Program Data and Information System (IGBP-DIS, 1998) based in France (Fig. 3).

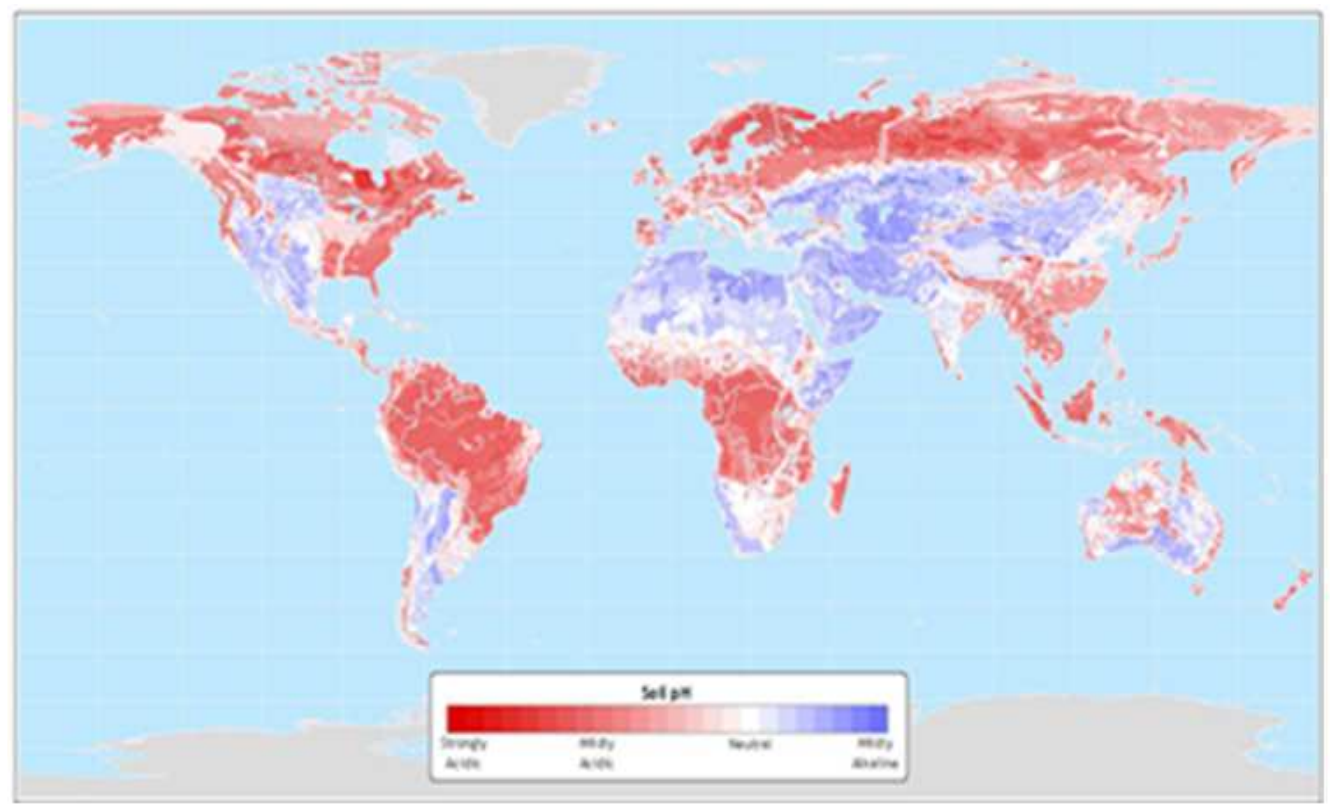

Fig. 3. Showing the Global variation in Soil $\mathrm{pH}$, Red $=$ acidic. Yellow $=$ natural, Blue $=$ alkaline, Black $=$ no data; Source: IGBP-DIS (1998) in Atlas of the Biosphere, Nelson Institute - Center for Sustainability and Global Environment. 
The various contributors to the issue of soil $\mathrm{pH}$ range from environmentalists, agriculturists, geologists, to public health officers. To understand soil $\mathrm{pH}$ there is need to appreciate that soil consists of various components that determine its properties. These include mineral particles (sand, silt and clay, which give soil its texture), organic matter (living and dead), air and water. The water component is where $\mathrm{pH}$ is measured and where dissolved chemicals that cause the soil to be acidic or alkaline are found (Belinda, 2000). Brenda's observation confirms soil acidity as a major environmental issue in a typical rain forest belt. The abbreviation $\mathrm{pH}$ stands for parts Hydrogen as the ability to release Hydrogen to a chemical reaction is one characteristic of an acid (IGBP-DIS, 1998). But Gu and Crouse (2010) said that, The letters " $\mathrm{pH}$ " mean "potential hydrogen." The soil $\mathrm{pH}$ is a measure of the acidity or alkalinity in soils (Sparks, 2003). When you think of $\mathrm{pH}$, you probably think of liquid acids and bases of scale ranging from 0 to 14 (Vernier, 2013). In this scale, 0 is a highly acidic value, 14 is highly alkaline and 7 is perfectly neutral.

Soil $\mathrm{pH}$, is sometimes referred to as soil acidity. Soils with $\mathrm{pH}$ above 7 are basic or sweet. Soils with $\mathrm{pH}$ below 7 are acidic or sour. By definition, $\mathrm{pH}$ is the "negative logarithm of the hydrogen ion concentration $\left[\mathrm{H}^{+}\right]$', i.e., $\mathrm{pH}=-\log \left[\mathrm{H}^{+}\right]$. Because $\mathrm{pH}$ is a logarithmic function, each unit on the $\mathrm{pH}$ scale is ten times less acidic (more alkaline) than the unit below it. For example, a solution with a $\mathrm{pH}$ of 6 has a 10 times greater concentration of $\mathrm{H}+$ ions than a solution with a $\mathrm{pH}$ of 7 . It also has a 100 times higher concentration than a $\mathrm{pH} 8$ solution (McCauley et al., 2009). They went further to explain that, a logarithmic scale is used to measure a soil's $\mathrm{pH}$. That is, a change of one unit in the $\mathrm{pH}$ scale represents a 10-fold change in acidity or alkalinity. A soil with a $\mathrm{pH}$ of 5.0 is 10 times more acidic than a soil with a $\mathrm{pH}$ of 6.0 and 10 many times more acidic than a soil with a $\mathrm{pH}$ of 7.0.

Soil $\mathrm{pH}$ influences the solubility of nutrients. It also affects the activity of microorganisms responsible for breaking down organic matter and most chemical transformations in the soil. Most garden plants thrive well at a pH between 6 and 7. Many heavy metals become more water soluble under acid conditions and can move downward with water through the soil and sometimes move to aquifers, surface streams, or lakes. According to the research of Dirisu and Alao (2010), as soil $\mathrm{pH}$ decrease, nutrient such as phosphorus usually decrease in availability due to reactions with aluminum and iron. Most minerals and nutrients are more soluble or available in acid soils than in neutral or slightly alkaline soils. Phosphorus is never readily soluble in the soil but is most available in soil with a pH of 6.5 . Excessive or wrong application of certain fertilizers results in acidification of soil, (Dirisu and Alao, 2010). Also Martin (2010) found that the continuously and conventionally-tilled plots share the lowest soil $\mathrm{pH}$. This he said was probably because of mining of exchangeable cat ions by growing crops in continuously tilled plots. Wet soil tend to be more acidic than dry soils, as chemicals which would otherwise neutralize the $\mathrm{pH}$ level get washed away before they have a chance to react, (IGBP-DIS, 1998). The sources of low soil pH can be either natural or human-induced. An increase in rainfall causes increased leaching of base cat ions and the soil $\mathrm{pH}$ is lowered (McCauley et al., 2009).

Dirisu and Alao (2010) also stated that the release of carbon dioxide from decomposing organic matter and rock dissolving in soil water form weak and strong organic acids. Acid such as hydrogen trioxonitrate (V) acid $\left(\mathrm{H}_{2} \mathrm{NO}_{3}\right)$ and Hydrogen tetraoxosulphate (VI) acid (H2SO4) from decaying organic matter and oxidation of ammonium fertilizer are usually formed. Also according to Crozier et al. (2003), the chemical makeup of clay and organic matter gives them net negative charges, meaning they can attract positively charged cat ions. Dirisu and Alao (2010) also found out that human activities have affected productivity of soil through soil pollution by altering its $\mathrm{pH}$. Hence, the findings revealed that natural soils in Omoku, River state Nigeria have low $\mathrm{pH}$ indicating slight acidity, mean $\mathrm{pH}$ of 6.03 ; while fertilizer-enriched soils is strongly acidic with a mean $\mathrm{pH}$ of 5.4. Nitrogen fertilizer increases soil acidity. Harvest of high yielding crops play the most significant role in increasing soil acidity. Acid rain is a second significant worldwide source of nitric and sulfuric acids. Nitrogen and sulfur-containing gases are emitted into the atmosphere from the combustion of coal gasoline and other fossil fuels as well as from burning of forest.

In their research on soil $\mathrm{pH}$ in Montana and Wyoming, McCauley et al. (2009) found out that Soil $\mathrm{pH}$ is influenced by both acid and base-forming ions in the soil. Common acid-forming cat ions (positively charged dissolved ions) are hydrogen $\left(\mathrm{H}^{+}\right)$, aluminum $\left(\mathrm{Al}^{3+}\right)$ and iron $\left(\mathrm{Fe}^{2+}\right.$ or $\left.\mathrm{Fe}^{3+}\right)$, whereas common baseforming cat ions include calcium $\left(\mathrm{Ca}^{2+}\right)$, magnesium $\left(\mathrm{Mg}^{2+}\right)$, potassium $\left(\mathrm{K}^{+}\right)$and sodium $\left(\mathrm{Na}^{+}\right)$and that most agricultural soils that have basic conditions with average $\mathrm{pH}$ values range from 7 to 8 . According to Harris et al. (1996) a range of 6 to 7 is generally most favorable for plants growth because most plant nutrients are readily available in this range. However, some plants have high soil $\mathrm{pH}$ requirement above or below the range. The availability of nutrients is directly affected by soil $\mathrm{pH}$. If the soil's $\mathrm{pH}$ is too high or too low, some nutrients become insoluble, limiting the availability of these nutrients to the plant root system ( $\mathrm{Gu}$ and Crouse, 2010).

Vernier (2013) in his study said that, the availability of these nutrients depends not only on the amount but also on the form that is present, on the rate they are released from the soil and on the $\mathrm{pH}$ of the soil. There is always a lot of aluminum present in soils because of its position as the most abundant earth's metal and its 
predominance in clay particles (Gordon and Hailin, 2013). High $\mathrm{pH}$ soil may have an inadequate availability of iron, manganese, copper, zinc and especially of phosphorus and boron (Sparks, 2003). A soil $\mathrm{pH}$ of 5.2 to 8.0 provides optimum conditions for most agricultural plants. All plants are affected by the extremes of $\mathrm{pH}$ but there is wide variation in their tolerance of acidity and alkalinity. Some plants grow well over a wide $\mathrm{pH}$ range, whilst others are very sensitive to small variations in acidity or alkalinity (Belinda, 2000). The "ideal" soil pH is close to neutral and neutral soils are considered to fall within a range from a slightly acidic $\mathrm{pH}$ of 6.5 to slightly alkaline $\mathrm{pH}$ of 7.5. It has been determined that most plant nutrients are optimally available to plants within this 6.5 to 7.5 $\mathrm{pH}$ range and this range of $\mathrm{pH}$ is generally very compatible to plant root growth Thomas (2010).

Several researchers and authors have tried in a number of ways to assess and classify soil pollution using statistical tools like pollution index, pollution factor, geo-accumulation index and enrichment factor. In all, they have applied their measurement tool mostly to metals pollution. Nwachukwu et al. (2010; Feng et al., 2004; Zhang et al., 2007; Bentum et al., 2011) etc have used enrichment or pollution indexes in different forms. According to Hong-Gui et al. (2012), Pollution factor weights are calculated according to different pollutants with varying degrees of harm to the environment and human body. Qingjie and Jun (2008), established that contamination factors (or concentration factors), ecological risk factor, enrichment factor and index of geo-accumulation are the powerful tools for ecological geochemistry assessment. According to Loska et al. (2003), the best results illustrating the degree of soil contamination with arsenic are achieved applying the index of geo-accumulation and enrichment factors calculated using logarithmized contents of reference elements-chromium and calcium. This paper appear to be the first in environmental literature material applying $\mathrm{pH}$ enrichment factor as a statistical tool for measuring soil acidity and assessing pollution.

\section{Materials and Methods}

Empirical and descriptive methods were used to collect data from both primary and secondary sources. Many published and unpublished works; journals, periodicals and magazines were consulted. Information obtained went a long way to providing the general background to the fieldwork. The study started with routine observation of activities that go on in the Nekede mechanic village and a reconnaissance study of the area was done at the beginning of the study. Some mechanics in groups of about twenty who were fascinated by the field measurements received informal education about environmental hazards associated with poor management of spent electrolyte and engine oil. Individuals who came for their vehicles and the union executives benefited.

\section{Instrumentation}

\section{Global Positioning System}

Garmin eTrex Waterproof Hiking GPS (Fig. 4a) was used to get the elevation and coordinates of all sampling and measurement points. The Garmin eTrex is a GPS unit targeted for outdoor enthusiasts with a highsensitivity receiver that locks onto satellite signals for quick pick up and maintenance of accuracy. Designed in a yellow colored form factor with an interface and a rugged exterior, the device is a lightweight handheld that fits in the palm of a hand. The high-sensitivity WAASenabled GPS receiver locates position quickly and maintains location even in heavy cover and near tall buildings. The elevation survey was run using the same GPS at selected points within the mechanic village. By this survey, both elevation in feet and coordinates were measured at grid spots. The elevation map helped to determine drainage direction, so that soil $\mathrm{pH}$ measurement could be run in the direction of natural drainage.

\section{In-Situ pH Meter}

The $\mathrm{pH}$ was measured with Digital In-situ $\mathrm{pH}$ Meter: Kelway Soil Tester, manufactured by Kel Instruments Company (Fig. 4b). It is a professional-grade tool that measures soil acidity directly in the soil. It is a sensitive electronic device that measures soil $\mathrm{pH}$ values from 3.5 to 8 and requires no chemical, distilled water, or outside electric power source. The tester uses a tiny flow of electric current through the metal plates to measures soil $\mathrm{pH}$. The plates must have good contact with the soil and the needle on the round face of the meter must point to " 7 " before testing (pushing the white button). With the simple-to-operate, precision meter, on-the-spot soil $\mathrm{pH}$ was determined.

\section{pH Measurement Field Techniques}

Soil $\mathrm{pH}$ was randomly measured at predetermined points along the direction of drainage in the mechanic village. Measurement points were identified within the drainage area which also followed the mechanic village roads (Fig. 5A-D). pH readings were also conducted randomly at ten auto electrical workshops. At each location, soil was tested to $8 \mathrm{~cm}$ depth. The $8 \mathrm{~cm}$ probe is usually driven into the earth with full grip to the soil. Moisture content of soil is essential to the instrument response. A background study of $\mathrm{pH}$ was similarly conducted at a location $1 \mathrm{~km}$ off the mechanic village and against the direction of drainage. A profile was chosen to accommodate a number of $\mathrm{pH}$ measurements at predetermined intervals. 

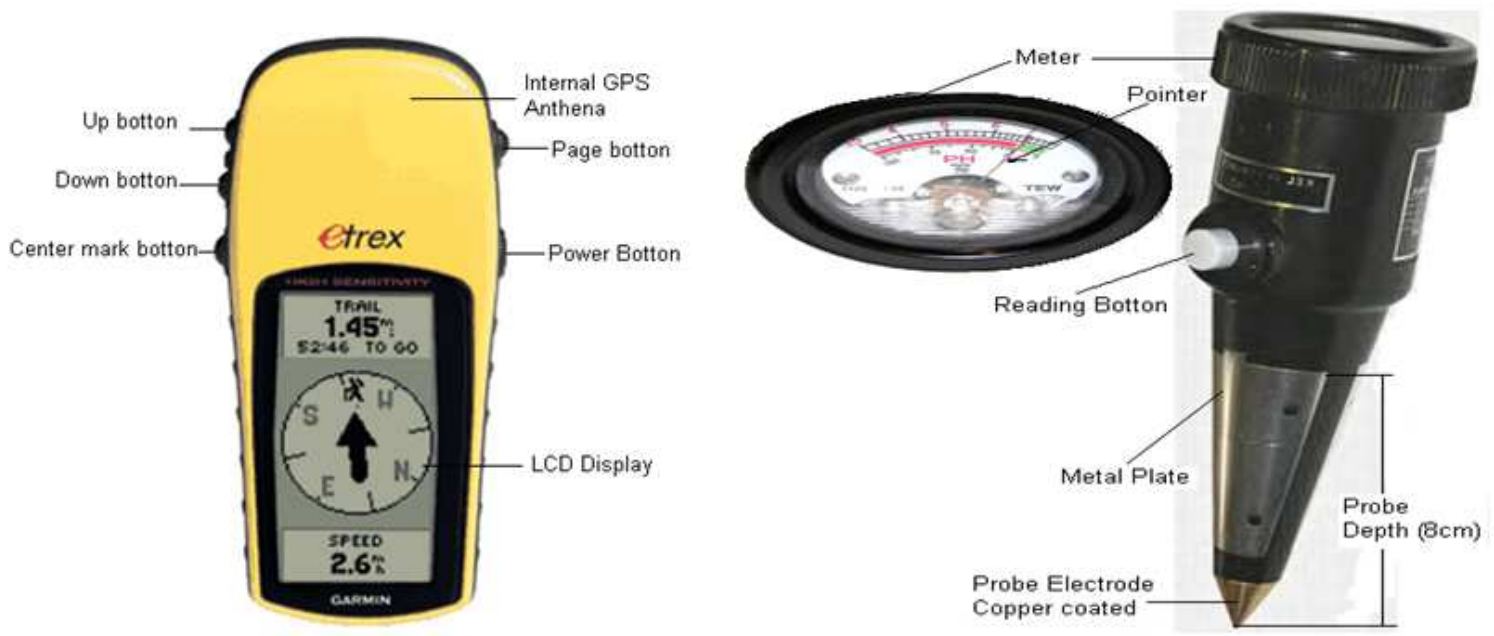

Fig. 4. (a) Garmin eTrex waterproof hiking GPS, (b) Digital in-situ pH meter



Fig. 5. Sketch of the Nekede mechanic village showing roads A-D and their sectional view

\section{Data Processing}

Sequel to the field investigation and observation at Nekede mechanic village and environs, data generated from the soil $\mathrm{pH}$ measurement (in-situ), $\mathrm{pH}$ of Otamiri
River (laboratory), elevation and coordinates were collated. Analysis of each using Excel package presented $\mathrm{pH}$ composite graphs of each measurement traverse. Data was critically analyzed to determine degree of acidity based on $\mathrm{pH}$ enrichment index. Result was 
justified with pollution index obtained by Nwachukwu et al. (2010; 2011), confirming $\mathrm{pH}$ as pollution indicator.

\section{pH Enrichment Factor $\left(\mathrm{pH}_{f}\right)$ and Pollution Index (Pi)}

$\mathrm{pH}$ enrichment index is a statistical parameter developed in this research to represent the degree of acidity. Since $\mathrm{pH}$ is not a pollutant, but an indicator of pollution, then $\mathrm{pH}$ enrichment index was compared with pollution index. The goal was to understand the relationship between $\mathrm{pH}$ enrichment index and pollution index. This relationship was confirmed by determining correlation coefficient between $\mathrm{pHeF}$ and Pi of the Nekede mechanic village soil. The following equations were applicable:

$p H$ Enrichment factor $\left(p_{H} e_{f}\right)=\frac{\text { Mean } p H(B)}{\text { Mean } p H(M)}$

Where:

$p H(M)=\mathrm{pH}$ of mechanic village soil

$p H(B)=\mathrm{pH}$ of background soil

Pollution Index $(P i)=\frac{M C}{B C}$

Where:

$M C=$ Concentration of heavy metals in the mechanic village soil

$B C=$ Concentration of heavy metals in the background soil

pH Enrichment Threshold

$=\frac{\text { Mean } p H \text { Background }+ \text { Mean } p H \text { Mechanic village }}{2}$

\section{Correlation Coefficient}

This is used in this study to measure how strong the relation is between $\mathrm{Pi}$ and $p H e \mathrm{~F}$ variables. The well known measure of dependence (Pearson's correlation) was applied. The correlation coefficient always takes a value between -1 and 1 , with 1 or -1 indicating perfect correlation. A positive correlation indicates a positive association between the variables while a negative correlation will indicates a negative association between the $\mathrm{Pi}$ and $\mathrm{pHeF}$ A correlation value close to 0 indicates no association between the two variables. There are many formulas to calculate the correlation coefficient (r), all yielding the same result. In this study, the applicable equation is:

$$
\begin{gathered}
\text { Correlation coefficient }=r= \\
\frac{\sum_{i}\left(x_{i}-\bar{x}\right)\left(y_{i}-\bar{y}\right)}{\sqrt{\sum_{i}\left(x_{i}-\bar{x}\right)^{2} \sqrt{\sum_{i}\left(y_{i}-\bar{y}\right)_{2}}}}
\end{gathered}
$$

The $\bar{x}$ and $\bar{y}$ represents the mean of the data set $\mathrm{Pi}$ and $p H e \mathrm{~F}$ respectively, where $i$ is the number of samples.

\section{Supplementary Activities:}

- All field observations and activities were recorded and documented in photographs

- Proximity of Otamiri River to the mechanic village and storm water discharge points from the mechanic village to the Otamiri River was determined

- Some of the mechanics, especially the auto electricians involved in changing battery acid were interviewed; interacting with them about the method of disposing their waste. It was excellent educating them on the implications of disposing used acid and oil on the ground. The effects on the environment; effects of acidity on crops and vegetables and the effects on human health were highlighted

\section{Laboratory Tests}

Laboratory determination of $\mathrm{pH}$ on water samples from Otamiri River within the Nekede mechanic village was carried out in order to assess the level of impact of Nekede mechanic village on the $\mathrm{pH}$ level of Otamiri River. Water sample were collected using plastic water sample bottles. Sample collection was made $500 \mathrm{~m}$ upstream before the mechanic village and $500 \mathrm{~m}$ downstream after the mechanic village. Collected samples were tested for $\mathrm{pH}$ using $\mathrm{pH}$ meter (PHS-3C) manufactured by SHENGCI Water.

\section{Result and Discussion}

\section{Environmental Field Assessments}

Important field observations were captured in photographs, representing the physical appearance of Nekede mechanic village (Fig. 4), against each investigated road. Greater of the mechanic village activities go on in the open air and on natural ground surface. The entire area is highly congested with unserviceable vehicles and vehicles undergoing repairs. The earth roads are in deplorable conditions, almost impassable in rainy seasons. The environment is hostile to the mechanics and other allied workers including little children dwelling within.

\section{Analysis of $\mathrm{pH}$ Measurement}

Figure $6 \mathrm{a}$ and $6 \mathrm{~b}$ are bar charts, showing result of in-situ $\mathrm{pH}$ tests of soil at road A and B traverse across the mechanic village. Figure $7 \mathrm{a}$ and $7 \mathrm{~b}$ are bar charts; showing result of in-situ $\mathrm{pH}$ tests of soil at roads $\mathrm{C}$ and D. Figure 8 represent in-situ levels of soil $\mathrm{pH}$ around auto-electrical workshop areas, while Fig. 9 is 
showing result of in-situ $\mathrm{pH}$ tests of soil at a control traverse off the mechanic village, representing the background values. Figure 10 is a spectral display showing spatial variation of $\mathrm{pH}$ in Nekede mechanic village, against the local background values. From Fig. 5 it is obvious that soils along roads A-D of the Nekede mechanic village have $\mathrm{pH}$ below 6.5 , with average $\mathrm{pH}$ of 4.14 in road A. Road B has average of 4.12, road C, 4.06 and road D 3.99. Average $\mathrm{pH}$ as

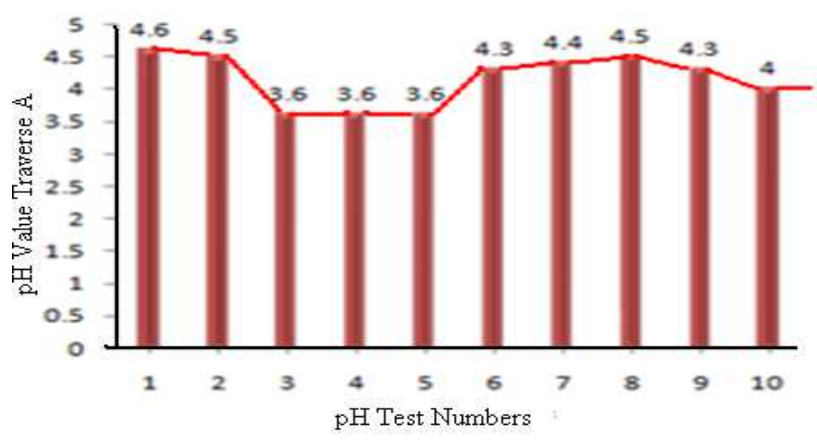

low as 3.52 was obtained in E, being selected autoelectrical workshop areas, while 7.07 was obtained as average $\mathrm{pH}$ at the background traverse. This indicates a low $\mathrm{pH}$ of the average of 3.96 in the mechanic village which is highly acidic. This result shows that some locations in the mechanic village soil are more acidic due to random discharge of spent electrolyte on the ground by auto electricians and corrosion of scrap metals that litter.

Fig. $6 \mathrm{a}$ and $6 \mathrm{~b}$ showing result of in-situ $\mathrm{pH}$ tests of soil at roads $\mathrm{A}$ and $\mathrm{B}$
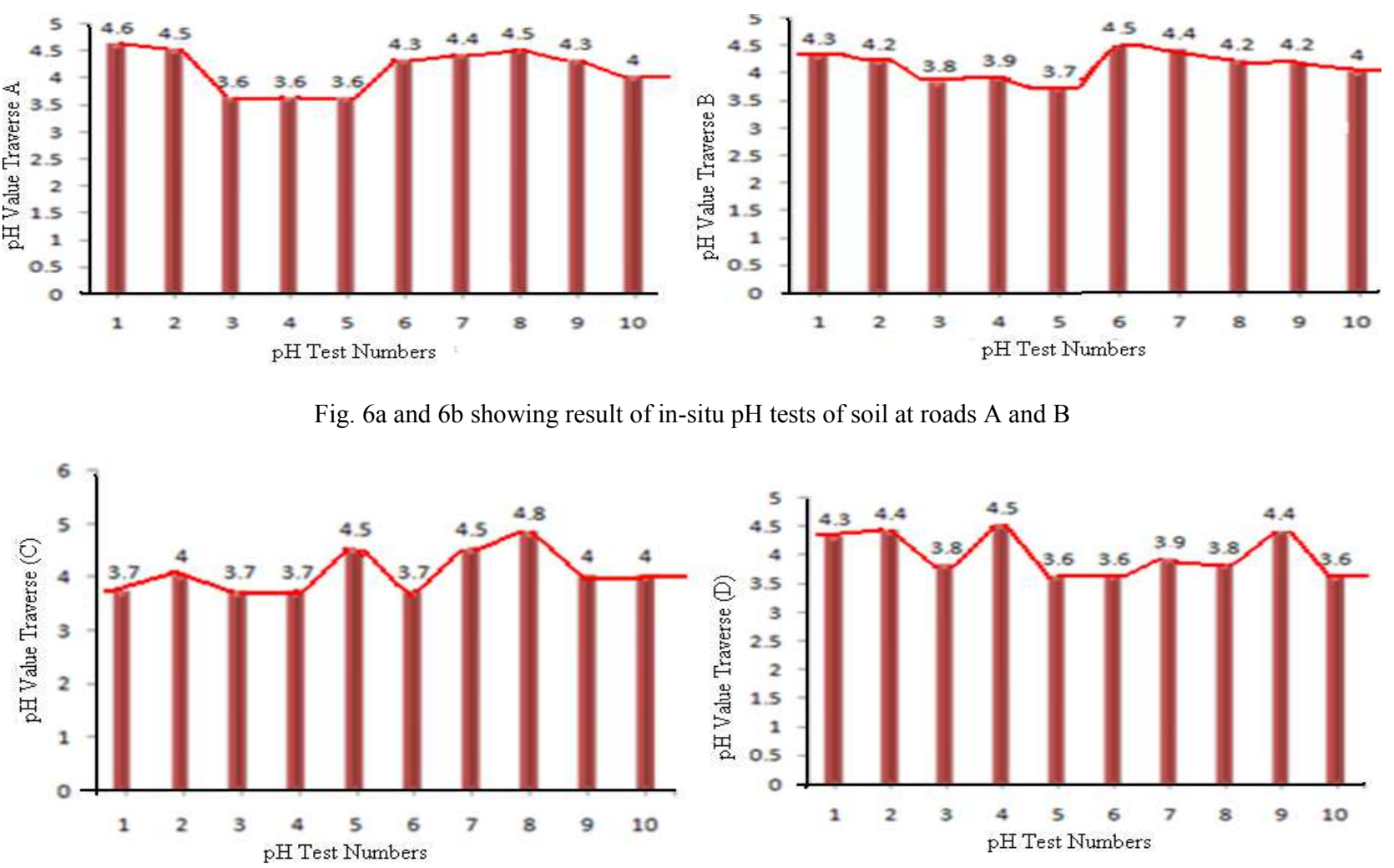

Fig. 7a and $7 \mathrm{~b}$ showing result of in-situ $\mathrm{pH}$ tests of soil at roads $\mathrm{C}$ and $\mathrm{D}$

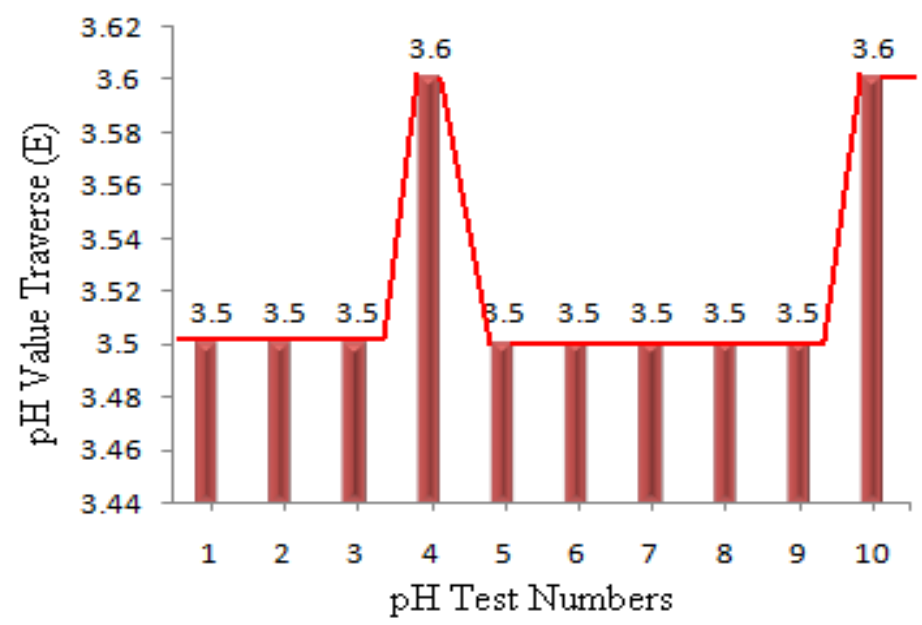

Fig. 8. Shows in-situ $\mathrm{pH}$ tests around auto-electrical shops 


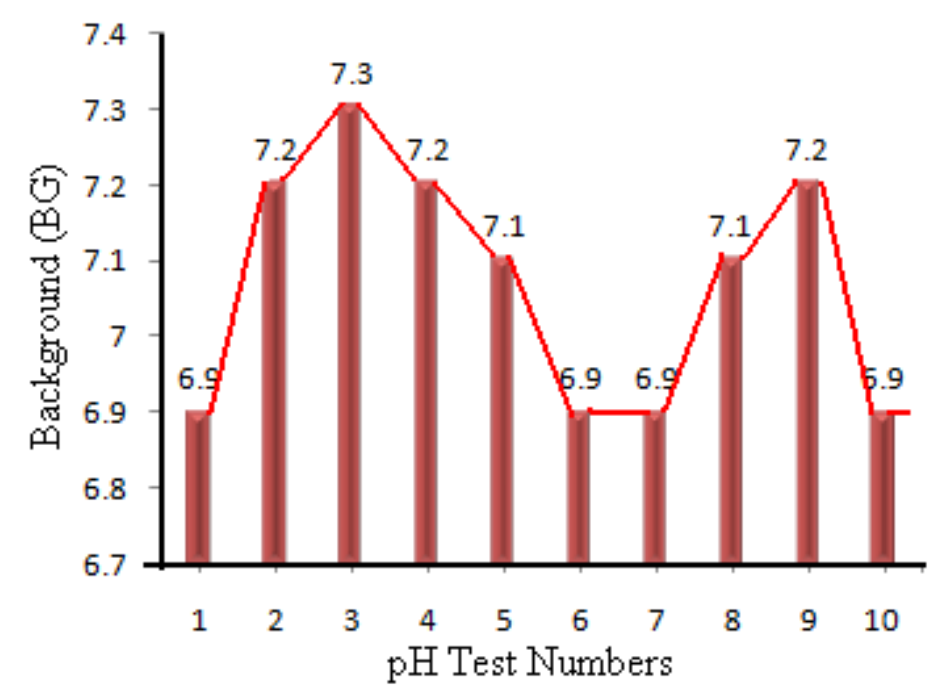

Fig. 9. In-situ pH of the local background value (Control) Road E

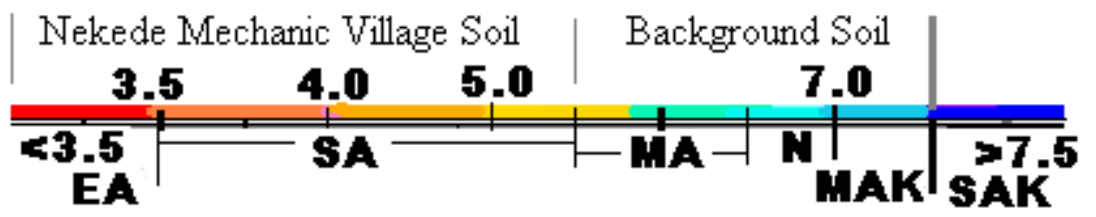

Fig. 10. Spectral display of soil $\mathrm{Ph}$; Nekede mechanic village and local Background

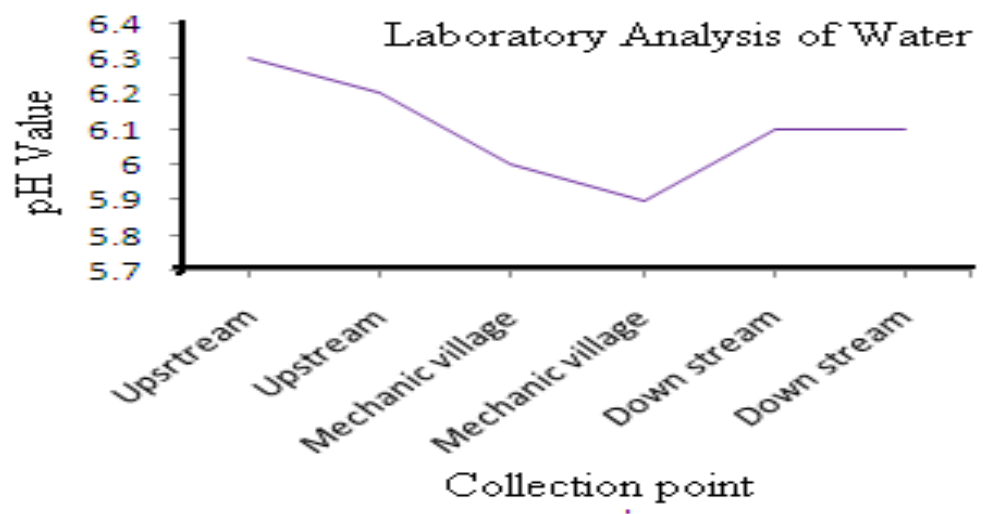

Fig. 11. Laboratory result of Otamiri river (water $\mathrm{pH}$ )

Analysis of Fig. 6-8 classifies the enrichment of $\mathrm{pH}$ in mechanic villages' soils against $\mathrm{pH}$ of local background soils. The spectral display (Fig. 10), confirmed that mechanic village soil could be strongly to excessively acidic where the local background $\mathrm{pH}$ is moderately acidic to neutral or strongly alkaline. EA = Excessively Acidic; SA = Strongly Acidic; MA = Moderately Acidic; $\mathrm{N}=$ Neutral MAK = Moderately Alkaline; SAK = Strongly Alkaline.

Laboratory analyses of Otamiri River across the study area clearly indicate high acidity within the mechanic village area (Fig. 11). There is low to moderate acidity in the upstream segment, strong acidity in the mechanic village area and moderate acidity in the downstream segment due to natural dilution.

\section{Result Justification}

As presented in Table 1 and 2, pHeF have strong relationship with $\mathrm{Pi}$ and with a Correlation coefficient (r): 0.8 , making the two parameters considerable tools for heavy metal pollution assessment. This correlation is in line with the findings of Deka and Sarma (2012), 
Whyttenbach and Bajo (1991) that coefficient of correlation between heavy metals and other soil properties such as $\mathrm{pH}$ established a nonlinear relationship. According to Matos et al. (2001), soil pH influenced the heavy metals adsorption and movement as shown by the significant correlation with the retardation factors when the combined data for the unlimed and limed Brazilian soils samples were tested. It is important to state that variation in soil moisture even between wet and dry seasons will not affect the value of $p H e \mathrm{~F}$ This is because the two players in calculating $p H e \mathrm{~F}$ being $\mathrm{Ph}$ of soil in the contaminated site and that in the background will respond equally to moisture variation.

While $\mathrm{Pi}$ range was obtained as 1.6-2.1, $\mathrm{pHeF}$ range was obtained as 1.7-2.0 at Nekede mechanic village. This revelation suggest that in a heavy metal contaminated topsoil $(0-10 \mathrm{~cm}$ depth), $p H e \mathrm{~F}$ tends to Pi. The analysis shown in Table 1 and 2 justify the bases on which $p H e \mathrm{~F}$ and $\mathrm{Pi}$ can be compared. For example, $p H e \mathrm{~F}=1=$ No acidity and $\mathrm{Pi}=1=$ No pollution. In this case, the soil condition for both $p H e \mathrm{~F}$ and $\mathrm{Pi}$ is neutral. $\mathrm{pHe} \mathrm{F}<1=$ Alkalinity and $\mathrm{Pi}$
$<1=$ No pollution. $p H e \mathrm{~F}>1=$ Acidity, as $\mathrm{Pi}>1=$ pollution.

The degree of acidity and pollution increases simultaneously with increases in the values of $p H e F$ and $\mathrm{Pi}$ from 1. This justifies the use of $p H e \mathrm{~F}$ and $\mathrm{Pi}$ as comparative statistical tools in soil pollution assessment and qualitative classification. The use of $p H e \mathrm{~F}$ singularly in qualitative assessment of soil pollution becomes obvious where classical instrument for heavy metal analysis is not readily available.

Many researchers described $\mathrm{pH}$ as pollution indicator rather than a pollutant, yet high acidity in soil, water and air cause toxicity and health problems to plants, man and other organisms. Not much work has been done to test $\mathrm{pH}$ singularly as pollution indicator and as a tool for fast, cheap and reliable field qualitative assessment of the degree of pollution. Using $\mathrm{pH}$ enrichment factor $(\mathrm{pHeF})$ will eliminate the trouble of cost, availability, rigorous laboratory procedure and maintenance of sophisticated spectroscopy for heavy metal analysis. In an isolated limited land area suspected to be contaminated or a degraded parcel of land, $\mathrm{pHeF}$ can easily be used for immediate field assessment and decision making.

Table 1. Analysis of $\mathrm{pH}$ measurement

\begin{tabular}{|c|c|c|c|c|c|c|}
\hline $\begin{array}{l}\text { pH test } \\
\text { number }\end{array}$ & $\begin{array}{l}\text { Traverse } \\
\text { Road A }\end{array}$ & $\begin{array}{l}\text { Traverse } \\
\text { Road B }\end{array}$ & $\begin{array}{l}\text { Traverse } \\
\text { Road C }\end{array}$ & $\begin{array}{l}\text { Traverse } \\
\text { Road D }\end{array}$ & $\begin{array}{l}\text { Electrical } \\
\text { workshops (E) }\end{array}$ & $\begin{array}{l}\text { Background } \\
\text { (BG) }\end{array}$ \\
\hline 1 & 4.60 & 4.30 & 3.70 & 4.30 & 3.50 & 6.90 \\
\hline 2 & 4.50 & 4.20 & 4.00 & 4.40 & 3.50 & 7.20 \\
\hline 3 & 3.60 & 3.80 & 3.70 & 3.80 & 3.50 & 7.30 \\
\hline 4 & 3.60 & 3.90 & 3.70 & 4.50 & 3.60 & 7.20 \\
\hline 5 & 3.60 & 3.70 & 4.50 & 3.60 & 3.50 & 7.10 \\
\hline 6 & 4.30 & 4.50 & 3.70 & 3.60 & 3.50 & 6.90 \\
\hline 7 & 4.40 & 4.40 & 4.50 & 3.90 & 3.50 & 6.90 \\
\hline 8 & 4.50 & 4.20 & 4.80 & 3.80 & 3.50 & 7.10 \\
\hline 9 & 4.30 & 4.20 & 4.00 & 4.40 & 3.50 & 7.20 \\
\hline 10 & 4.00 & 4.00 & 4.00 & 3.60 & 3.60 & 6.90 \\
\hline Average & 4.14 & 4.12 & 4.06 & 3.99 & 3.52 & 7.07 \\
\hline \multicolumn{5}{|c|}{ Mean $\mathrm{pH}$ of mechanic village soil $=3.96 ;$ Threshold } & \multirow{2}{*}{\multicolumn{2}{|c|}{2.00}} \\
\hline$p H e \mathrm{~F}=$ & 1.70 & 1.71 & 1.74 & 1.77 & & \\
\hline
\end{tabular}

pHeF Range: 1.7-2.0

Mean $=1.8$

Table 2. Analysis of heavy metal assessments based on Nwachukwu et al. $(2010 ; 2011)$

\begin{tabular}{lccc}
\hline Heavy metal & Nekede background soil & Nekede Mech. village & Pollution \\
Depth: 0-10 cm & Average value $\left(\mathrm{mg} \mathrm{L}^{-1}\right)$ & 18.3 & 1.7 \\
$\mathrm{Ni}$ & 11.0 & 20.0 & 1.9 \\
$\mathrm{Cd}$ & 17.2 & 592.0 & 1.9 \\
$\mathrm{~Pb}$ & 309.0 & 385.0 & 1.6 \\
$\mathrm{Cu}$ & 248.0 & 16.8 & 2.0 \\
$\mathrm{Cr}$ & 8.2 & 627.0 & 1.7 \\
$\mathrm{Mn}$ & 374.0 & 577.0 & 2.1 \\
$\mathrm{Zn}$ & 274.0 & 49295.0 & 1.6 \\
$\mathrm{Fe}$ & 31582.0 & & \\
$\mathrm{Pi}$ Range: $1.6-2.1$; Mean Pi: 1.8 & &
\end{tabular}




\section{Impact of Nekede Mechanic Village on the pH of} Otamiri River

As a Complementary Investigations (Fig. 10) represents the $\mathrm{pH}$ data obtained from water samples collected from the Otamiri River that passes behind the mechanic village. Storm water from the mechanic village discharges into this river. This graph shows $\mathrm{pH}$ parity along the river course, $500 \mathrm{~m}$ upstream and $500 \mathrm{~m}$ downstream as against the river portion within the mechanic village area. The relatively low values of $\mathrm{pH}$ recorded in water samples collected from the Otamiri River directly behind the Nekede mechanic village confirms negative impact of the mechanic village on Otamiri River. The values indicate acidity and possible trace metal pollution in the river.

Figure 10 clearly illustrates the high $\mathrm{pH}$ value upstream, $500 \mathrm{~m}$ preceding the mechanic village at $6.2-$ $6.3 \mathrm{pH}$. Relatively lower $\mathrm{pH}$ values 6.0-5.9 were obtained on samples collected behind the mechanic village, while $\mathrm{pH}$ of 6.1 was recorded downstream at 500 $\mathrm{m}$ after the mechanic village. The analysis shows that the activities in the mechanic village contributes in rendering the water unfit for drinking and other domestic use except otherwise treated.

\section{Depth to Water Table}

Water table in the area is shallow, fluctuates between 26-38 m (Nwachukwu et al., 2012). Groundwater at this depth is vulnerable to pollution by surface contaminants and increasing acidity from surface infiltration in view of the porous sandy subsurface typical of the Benin Formation in the area.

\section{Summary}

The study has exposed the Poor management of occupational waste (used battery acid) as the primary cause of high acidity of soil within the Nekede mechanic village. This study has discovered $p H e \mathrm{~F}$ as a statistical tool for pollution assessment comparable with Pi. Result shows that $p H e \mathrm{~F}$ have strong relation with $\mathrm{Pi}$ and both are reliable tools for assessment of heavy metal polluted soils. While Pi range was obtained as 1.6-2.1, with a mean value of 1.8, $p \mathrm{HeF}$ range was obtained as 1.7-2.0 with same mean value of 1.8 . This revelation suggest that in a heavy metal contaminated topsoil $\quad(0-10 \quad \mathrm{~cm}$ depth), $p H e$ F tends to Pi. From the analysis, a $p H e F$ of 1 implies a Pi of 1 , which indicates zero pollution. In this case, the soil condition for $p H e \mathrm{~F}$ and $\mathrm{Pi}$ is neutral. $p H e \mathrm{~F}$ $<1=$ Alkalinity and $\mathrm{Pi}<1=$ No pollution. $p H e \mathrm{~F}>1=$ Acidity and $\mathrm{Pi}>1=$ pollution. This implies that not only is $p H e \mathrm{~F}$ a pollution indicator, it is also a statistical tool for classifying degree of soil pollution. The poor management of used electrolyte by auto-electricians in mechanic villages has negative consequences on soil and water (including ecology, public health and the overall quality of the environment. Many mechanic villages should be zoned out of their present locations to improve environmental quality and health.

Nekede mechanic village in particular is not properly situated. There is therefore need for immediate remediation program based on 5 year span sustainability study of soil $\mathrm{pH}$ level in Nekede mechanic village. The soil within and around Nekede Mechanic village needs urgent clean up to minimize contamination of ecological materials. The $\mathrm{pH}$ is the most parameter in the bio sorption process that affects the metals, the activities of the functional groups in the biomass and the competition of metallic ions. Though $\mathrm{pH}$ is not a parameter for contaminants, it can be used to know the degree of pollution in soil and water. The Nekede mechanic village demands immediate relocation by government in view of its environmental degradation and proximity to residential areas.

Both extremely high and extremely low $\mathrm{pH}$ soils do not favor plant growth. A high acidity below the measured threshold $\mathrm{pH} 5.515$ may trigger toxicity to plants, while strong alkalinity above $\mathrm{pH} 7.5$ as measured, impairs uptake of important trace elements by the plants. The overall ecological impacts such as low nutrient availability to crops planted within and around mechanic villages calls for sustainability study. Finally as many developing countries chose mechanic village idea against the citywide auto workshop practice, the need for environmentally friendly mechanic villages becomes obvious.

\section{Remediation}

With average $\mathrm{pH}$ of 3.96 , mean $\mathrm{pHeF}$ of 1.8 and mean Pi of 1.8 , the Nekede mechanic village soil is under severe to excessive pollution and low nutrients availability. Therefore, there is need for significant environmental concern and immediate response to the problem. Disposing used electrolyte on the ground by auto electricians is dangerous. It is the major cause of increasing acidity in the soil. A remediation program by government of the Nekede mechanic village soil is unavoidable. A good point to begin the remediation engagements is to adapt measures that will prohibit the current practice of disposing spent electrolyte on the ground. Now there is no enforced rule about occupational wastes management in mechanic villages.

One effective method of increasing soil $\mathrm{pH}$ is the application of ground limestone. Limestone $\left(\mathrm{CaCo}_{3}\right)$ has natural ability to raise soil $\mathrm{pH}$. Dolomite may be preferable where available since it contains both calcium and magnesium, though not suitable in soil rich in magnesium (serpentine). This implies that the application of limestone or dolomite depends on soil type and texture. In the case of Nekede mechanic village, the soil is sandy, making the process of raising the soil 
$\mathrm{pH}$ easier than that of clay soil. Since limestone moves very slowly, taking few years to move some centimeters down in the soil, it should be fairly tilted into the top 10 $\mathrm{cm}$ soil. According to Anderson et al. (2013), about 0.5 ton of fine ground limestone is required per acre of land to raise the soil $\mathrm{pH}$ from 4.5 to 5.5 and 0.6 ton to raise the $\mathrm{pH}$ from 5.5 to 6.5 :

- $\quad$ Lime $($ Calcium + magnesium carbonate $)+$ water $=$ Calcium soil $+\mathrm{OH}$

- Lime will neutralize the acidity $-\mathrm{H}^{+}$ion concentration and will add calcium to the soil

\section{Conclusion}

Many researchers have described $\mathrm{pH}$ as pollution indicator rather than be a pollutant on its own, yet high acidity in soil, water and air cause toxicity and health hazards. This study has not only confirmed $\mathrm{pH}$ as a pollution indicator, it has also introduced $\mathrm{pH}$ enrichment factor $(p H e \mathrm{~F})$ as a statistical tool comparable with pollution index (Pi) in assessing the degree of metal pollution in soil. It is an effective tool for heavy metal qualitative pollution assessment and classification. This study has confirmed that soil of Nekede mechanic village is under severe pollution in line with the work of Nwachukwu et al. (2010; 2011; Udebuani et al., 2011). Soil $\mathrm{pH}$ directly affects the life and growth of plants, because it affects all plant nutrients availability. Between 6.0-6.5, most plant nutrients are in their most available state. At average $\mathrm{pH}$ of 3.96 in the Nekede mechanic village soil, most plant nutrients are already degraded and thus not available to the plants. Future studies may investigate ecological impacts of increasing acidity in soil within and around mechanic villages. For example, the impacts of increasing soil acidity to nutrient availability in vegetables and crops planted around the mechanic village demands periodic study. We are therefore recommending $p H e \mathrm{~F}$ as a new statistical tool for pollution assessment, particularly in remote areas where spectroscopy may not be available and immediate information is needed for decision making.

\section{Acknowledgement}

The authors remain very grateful to GEOPROBE International Consultants Limited Owerri for instrumentation and logistics supports that enabled this research. Special thanks go to all the company staff who assisted in the fieldwork.

\section{Author's Contributions}

Michael Nwachukwu: Initiated, designed and supervised this research. He stands as the principal and correspondent author of this manuscript.
Okoro Uwaezu: She had this as her master's degree research project. She stands as the principal investigator in this study.

Ogbuja I. Ogbuja: Is a collaborator who was more involved in the laboratory instrumentation and the analytical techniques.

Nwosu Leonard: Provided the in-site $\mathrm{pH}$ meter and handled the field instrumentation for data collection, involved in the manuscript revision process.

\section{Ethics}

This manuscript is totally the result of original work of the authors and a continuation of previous researches conducted on mechanic villages by the principal author. No ethical issue is anticipated now and after publication of this manuscript.

\section{References}

Anderson, N.P., J.M. Hart, D.M. Sullivan, N.D. Christensen and D.A. Horneck et al., 2013. Applying lime to raise soil $\mathrm{pH}$ for crop production.

Belinda, L., 2000. Acid soil management, prepared for the New South Wales Acid Soil Action Program. Acid Soils Project.

Bentum, J.K., M. Anang, K.O. Boadu, E.J. KorantengAddo and A.E. Owusu, 2011. Assessment of heavy metals pollution of sediments from Fosu lagoon in Ghana. Bull. Chem. Soc Ethiop., 25: 191-196. DOI: $10.4314 /$ bcse.v25i2.65869

Crozier, H.C., D. Hardy, B. Walls and R. Reich, 2003. Soil Facts: Soil Acidity and Liming for Agric Soils.

Deka, J. and H.P. Sarma, 2012. Heavy metal contamination in soil in an industrial zone and its relation with $\mathrm{pH}$ and other soil properties. Arch. Applied Sci. Res., 4: 831-836.

Hong-Gui, D., G. Teng-Feng, L. Ming-Hui and D. Xu, 2012. Comprehensive assessment model on heavy metal pollution in soil. Int. J. Electrochem. Sci., 7: 5286-5296.

Dirisu, C.G. and A.A. Alao, 2010. Implication of reduced soil $\mathrm{pH}$ on sustainable food production in omoku community of rivers state, Nigeria: A comparative analysis of the ph of natural and chemical fertilizer-enriched soils. Int. J. Water Soil Resources Res., 1: 1-3.

Feng, X.B., G.H. Li and G.L. Qui, 2004. A preliminary study on mercury contamination to the environment from artisanal zinc smelting using indigenous methods in Hezhang county, Guizhou, China-Part 1: Mercury emission from zinc smelting and its influences on the surface waters. Atoms. Environ., 36: 6223-6230.

DOI: $10.1016 /$ j.atmosenv.2004.07.020 
Qingjie, G. and D. Jun, 2008. Calculating pollution indices by heavy metals in ecological geochemistry assessment and a case study in parks of Beijing. J. China Univ. Geosci., 19: 230-241. DOI: $10.1016 / \mathrm{S} 1002-0705(08) 60042-4$

Gordon, V.J. and Z. Hailin, 2013. Causes and effects of soil acidity. Oklahoma Cooperative Extension Service.

IGBP-DIS, 1998. A program for creating global soilproperty database, International GeosphereBiosphere Program Data and Information System, France.

Harris, J.A., P. Birch and J. Palmer, 1996. Land Restoration and Reclamation: Principles and Practice. 1st Edn., Longman, Harlow, ISBN-10: 0582243130, pp: 230.

Loska, K., D. Wiechuła, B. Barska, E. Cebula and A. Chojnecka, 2003. Assessment of arsenic enrichment of cultivated soils in southern Poland. Polish J. Environ. Stud., 12: 187-192.

Matos, A.T., M.P.F. Fontes, L.M. Costa and M.A. Martinez, 2001. Soil pH greatly influenced adsorption and movt of heavy metals: Mobility of heavy metals as related to soil chemical and mineralogical character of Brazil soils. Environ. Poll., 111: 429-435.

Martin, A.N.A., 2010. Carbon storage in soils of Southeastern Nigeria under different management practices. Carbon Balance Manag., 5: 5-5. DOI: $10.1186 / 1750-0680-5-5$

McCauley, A., C. Jones and J. Jacobsen, 2009. Nutrient management modules. Montana State University.

$\mathrm{Gu}, \mathrm{M}$. and K. Crouse, 2010. Soil $\mathrm{pH}$ and fertilizers extension service of Mississippi State University. Dept of Agric Pub in furtherance of Acts of Congress.

NPC, 2006. Nigerian national census. National Population Commission, Abuja, Nigeria.
Nwachukwu, M.A., H. Feng and J. Alinnor, 2010. Assessment of heavy metal pollution in soil and their implications within and around mechanic villages. Int. J. Environ. Sci. Tech., 7: 347-358. DOI: $10.1007 / \mathrm{BF} 03326144$

Nwachukwu, M.A., H. Feng and J. Alinnor, 2011. Trace metal dispersion in soil from auto-mechanic village to urban residential areas in Owerri, Nigeria. Proc. Environ. Sci., 4: 310-322. DOI: $10.1016 /$ j.proenv.2011.03.036

Nwachukwu, M.A., C. Ohuawunwa, I. Nwachukwu and U. Nnorom, 2012. Sustainable water supply from boreholes in neighborhood communities besieged by off-campus students. Int. J. Water Res. Environ. Eng., 4: 352-362. DOI: 10.5897/IJWREE12.023

Sparks, L.D., 2003. Environmental Soil Chemistry. 2nd Edn., Academic Press, London, ISBN-10: 080494803, pp: 352.

Thomas, L., 2010. Soil pH and the availability of plant Nutrients. IPNI Plant Nutrition \# 2.

Udebuani, A.C., C.I. Okoli, H. Nwaigwe and P. Ozoh, 2011. Effect of spent engine oil pollution on arable soil of nekede mechanic village owerri, Imo State Nigeria. Int. J. Natural Applied Sci., 7: 257-260.

Vernier, 2013. Soil pH-vernier software and technology. Investigating Environmental Science through Inquiry.

Whyttenbach, A.L. and T.S. Bajo, 1991. Correlations between soil ph and metal contents in needles of Norway spruce. Water Air Soil Pollut., 57: 217-226. DOI: $10.1007 / \mathrm{BF} 00282885$

Zhang, L.P., X. Ye and H. Feng, 2007. Heavy metal contamination in western Xiamen Bay sediments and its vicinity, China. Marine Poll. Bull., 54: 974-998. DOI: 10.1016/j.marpolbul.2007.02.010 